\title{
Hubungan Peringkat Akreditasi Institusi Pendidikan Diploma III Kebidanan dengan Hasil Uji Coba Uji Kompetensi Bidan Periode Juli 2013
}

\author{
Ani Kusumastuti, ${ }^{1}$ Tri Hanggono Achmad, ${ }^{2}$ Tina Dewi Judistiani, ${ }^{3}$ Dany Hilmanto, ${ }^{4}$ Anita D. Anwar, ${ }^{5}$ Sari Puspa \\ Dewi $^{6}$ \\ ${ }^{1}$ Mahasiswa Magister Kebidanan Universitas Padjadjaran \\ ${ }^{2}$ Departemen Biokimia dan Biologi Molekuler Fakultas Kedokteran Universitas Padjadjaran \\ ${ }^{3}$ Departemen Epidemiologi dan Biostatistik Fakultas Kedokteran Universitas Padjadjaran \\ ${ }^{4}$ Departemen Ilmu Kesehatan Anak Fakultas Kedokteran Universitas Padjadjaran \\ ${ }^{5}$ Departemen Obstetri dan Ginekologi Fakultas Kedokteran Universitas Padjadjaran \\ ${ }^{6}$ Departemen Ilmu Kesehatan Masyarakat Fakultas Kedokteran Universitas Padjadjaran
}

\begin{abstract}
Abstrak
Penjaminan mutu institusi pendidikan dilakukan melalui akreditasi institusi, sedangkan kualitas lulusan salah satunya dilakukan melalui uji kompetensi. Peringkat akreditasi yang baik akan menghasilkan uji kompetensi yang baik, namun berdasarkan hasil uji coba uji kompetensi bidan tahun 2012 didapatkan rerata nilai peserta dari institusi terakreditasi B memiliki nilai yang lebih rendah dari institusi yang terakreditasi C. Tujuan penelitian ini adalah mengetahui perbedaan nilai berdasarkan peringkat akreditasi dan hubungan peringkat akreditasi dengan nilai uji coba uji kompetensi. Penelitian dilakukan dengan analitik cross sectional menggunakan seluruh data peserta uji coba uji kompetensi bidan periode Juli 2013 dari Asosiasi Institusi Pendidikan Kebidanan Indonesia (AIPKIND) dan Badan Akreditasi Nasional Perguruan Tinggi (BAN-PT). Data dianalisis dengan Kruskal-Wallis, Post Hoc Mann Whitney, dan Somers'd. Perbedaan nilai didapatkan pada semua kelompok akreditasi institusi $(\mathrm{p}<0,001)$ dengan nilai median (minimal-maksimal) 61,67 $(19,44-78,33)$ akreditasi A, 54,44 (1,11-77,78) akreditasi B, dan 49,44 (2,78-80,00) akreditasi C $(\mathrm{p}<0,001)$. Hubungan yang lemah antara peringkat akreditasi institusi pendidikan dengan nilai uji coba uji kompetensi $(\mathrm{p}<0,001)$, baik dibandingkan dengan nilai median $(\mathrm{r}=0,22)$ maupun nilai batas lulus $(\mathrm{r}=0,23)$. Penelitian ini menunjukkan adanya perbedaan nilai uji coba uji kompetensi berdasarkan peringkat akreditasi dan adanya hubungan antara peringkat akreditasi institusi dengan hasil uji coba uji kompetensi bidan. Semakin baik peringkat akreditasi institusi maka semakin baik pula hasil uji coba uji kompetensi yang didapatkan.
\end{abstract}

Kata kunci: Akreditasi, institusi pendidikan, kompetensi. 


\title{
Correlation of Accreditation of Diploma III Midwifery Institution with Result Rating of Try Out Competencies in July 2013 Periode
}

\begin{abstract}
The assurance of educational institutions' quality can be conducted through educational institutions accreditation, whilst for the quality of graduates, one of which is performed by assessing the competency achievement through competency testing. Good accreditation ratings will generate good competency testing results, however the virtue of trial competency testing results of midwives in 2012 reported that the participants from B-accredited institutions earn lower average scores than those of the participants from $\mathrm{C}$-accredited institutions. The research objective was to determine the difference of the scores based on accreditation ratings and to determine the relationship between the accreditation ratings and the scores of trial competency testing. The research was cross sectional analytic using all participants data of the trial competency testing of midwives in period of July 2013 from AIPKIND (Indonesian Association of Midwifery Educational Institutions) and BAN-PT (National Accreditation Board for Higher Education). The data's was analysed using Kruskal-Wallis, Post Hoc Mann Whitney and Somers'd.The results suggest that the difference in scores is obtained in all groups of institutional accreditation $(\mathrm{p}<0.001)$ with a median score (minimum-maximum) of each accreditation group at $61.67(19.44-78.33)$ accreditation A, $54.44(1.11-77.78)$ accreditation B, and 49.44 (2.78-80.00) accreditation $\mathrm{C}(\mathrm{p}<0.001)$. This research also describes weak relationship between accreditation ratings of Educational Institutions of Diploma III Program in Midwifery and the scores of trial competency testing $(\mathrm{p}<0.001)$, either compared to the median score $(\mathrm{r}=0.22)$ or the passing grade $(r=0.23)$. The research shows that differences scores obtained in groups of institution accreditation and there is a relationship between accreditation ratings of Educational Institutions of Diploma III Program in Midwifery and trial competency testing results of midwives. The good accreditation ratings of educational institutions will also obtain good results of trial competency testing.
\end{abstract}

Keywords: Accreditation, educational institutional, competency

\section{Pendahuluan}

Bidan merupakan salah satu tenaga kesehatan pemberi pelayanan primer di Indonesia khususnya terkait kesehatan ibu dan anak. Kualitas bidan saat ini dianggap semakin menurun. Salah satu penyebabnya adalah kurangnya pengawasan terhadap institusi pendidikan kebidanan yang jumlahnya semakin meningkat. Hal ini akan berdampak pada peningkatan jumlah lulusan yang tidak diimbangi dengan mutu yang dihasilkan. ${ }^{1}$

Salah satu upaya pemerintah dalam melakukan pengawasan dan pembinaan institusi adalah dengan melakukan penilaian akreditasi institusi pendidikan. Akreditasi institusi pendidikan Diploma III Kebidanan hingga tahun 2011 dilakukan oleh dua institusi yang berbeda. Penilaian akreditasi bagi institusi yang berada di bawah naungan Kementerian Pendidikan dan Kebudayaan diberikan oleh BAN-PT, sedangkan bagi institusi pendidikan Diploma III Kebidanan di bawah naungan Kementerian Kesehatan diberikan oleh Pusat Pendidikan Tenaga Kesehatan (Pusdiknakes). ${ }^{2}$

Penilaian akreditasi sebuah institusi dilakukan secara menyeluruh pada proses dan kinerja serta keterkaitan antara tujuan, masukan, proses, dan keluaran institusi pendidikan. ${ }^{3}$ Institusi pendidikan Diploma III Kebidanan di Indonesia yang telah mendapatkan peringkat akreditasi dari BAN-PT sebanyak 485 institusi di tahun 2014, dari seluruh institusi pendidikan Diploma III Kebidanan yang berjumlah 729 institusi. ${ }^{4}$ Dengan demikian, masih terdapat 244 institusi yang belum mendapatkan penilaian akreditasi dari BAN-PT.

Uji kompetensi merupakan cara lain pemerintah untuk memberikan pengawasan institusi pendidikan. Kelulusan dalam uji kompetensi harus didapatkan oleh seluruh lulusan bidan sebagai salah satu syarat mendapatkan Surat Tanda Registrasi (STR) dan dapat secara legal berpraktik. ${ }^{5}$ 
Uji kompetensi bidan menggunakan uji tulis dengan jenis soal Multiple Choice Question (MCQ). Pelaksanaan uji coba uji kompetensi telah sesuai dengan prinsip pelaksanaan sebuah uji yang memerhatikan validitas, reliabilitas, feasibilitas, kredibilitas, dan memiliki dampak terhadap proses belajar mengajar. Hal ini terlihat dari proses pembuatan dan pemilihan soal, serta metode uji hingga pelaporan hasil uji. ${ }^{6-12}$

Uji coba uji kompetensi bidan dilakukan dengan prosedur yang sama dengan uji kompetensi sesungguhnya. Peserta uji coba adalah mahasiswa tingkat akhir dari intitusi pendidikan Diploma III Kebidanan yang merupakan kandidat bidan. Hal ini dilakukan sebagai upaya mensosialisasikan proses uji kompetensi yang harus dilalui seluruh mahasiswa setelah lulus untuk mendapatkan sertifikasi. Gambaran proses uji ditujukan kepada calon peserta uji kompetensi maupun kepada institusi pendidikan asal peserta. Uji coba uji kompetensi juga dapat membantu mengukur sejauh mana pencapaian suatu institusi pendidikan dibandingkan dengan standar lulusan nasional. Hasil uji coba uji kompetensi dapat digunakan sebagai bahan masukan dalam perbaikan proses pembelajaran. ${ }^{13}$

Hasil penilaian akreditasi yang baik diharapkan akan memberikan gambaran kualitas suatu institusi pendidikan yang baik. Dengan demikian, akan mendapatkan hasil uji coba uji kompetensi yang baik pula, namun kondisi ini belum tampak pada hasil uji coba uji kompetensi bidan tahun 2012. Hasil kegiatan tersebut menunjukkan bahwa institusi dengan akreditasi B $(50,34)$ mendapatkan nilai rerata yang lebih rendah dari institusi dengan akreditasi $\mathrm{C}$ $(52,25){ }^{6}$ Tujuan penelitian ini adalah untuk mengetahui perbedaan nilai hasil uji coba uji kompetensi bidan berdasarkan peringkat akreditasi institusi pendidikan dan juga mengetahui hubungan antara peringkat akreditasi institusi pendidikan dengan hasil uji coba uji kompetensi bidan periode Juli 2013.

\section{Metode}

Penelitian ini menggunakan metode analitik cross sectional dengan memanfaatkan data sekunder tentang akreditasi institusi pendidikan Diploma III Kebidanan yang didapatkan dari penelusuran website BAN-PT dan juga data hasil uji coba uji kompetensi bidan periode Juli 2013 yang dimiliki AIPKIND. Jumlah sampel adalah 15.261 peserta dari 255 institusi pendidikan
Diploma III Kebidanan di Indonesia. Perbedaan nilai dilakukan menggunakan analisis KruskalWallis yang dilanjutkan dengan analisis Post Hoc Mann Whitney, sedangkan hubungan antara peringkat akreditasi institusi dengan hasil uji coba uji kompetensi menggunakan analisis Somers'd.

\section{Hasil \\ Gambaran Responden dan Hasil Uji Coba Uji Kompetensi}

\section{Tabel 1 Sebaran Peserta Uji Coba Uji Kompetensi Bidan Indonesia Periode Juli 2013}

\begin{tabular}{cccc}
\hline $\begin{array}{c}\text { Peringkat } \\
\text { Akreditasi } \\
\text { Institusi }\end{array}$ & $\begin{array}{c}\mathbf{n} \\
\text { Institusi }\end{array}$ & n Peserta & $\mathbf{\%}$ \\
\hline A & 21 & 1133 & 7,43 \\
B & 68 & 4594 & 30,10 \\
C & 170 & 9534 & 62,47 \\
\hline Jumlah & $\mathbf{2 5 9}$ & $\mathbf{1 5 2 6 1}$ & $\mathbf{1 0 0}$ \\
\hline
\end{tabular}

Peserta uji coba uji kompetensi sebagian besar (9534 orang) berasal dari institusi pendidikan terakreditasi $\mathrm{C}$.

Uji yang dilakukan pada seluruh peserta menggunakan metode uji tulis berbentuk MCQ sebanyak 180 soal dalam waktu 180 menit. Hasil nilai yang didapatkan oleh peserta uji coba uji kompetensi tampak dalam gambar 1 .

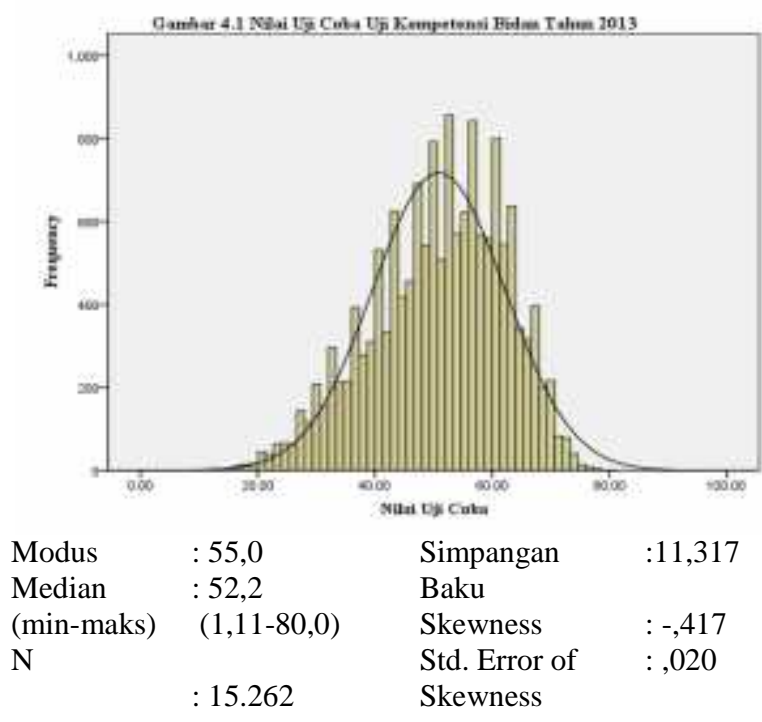

Gambar 1 Nilai Uji Coba Uji Kompetensi Bidan Periode Juli 2013 


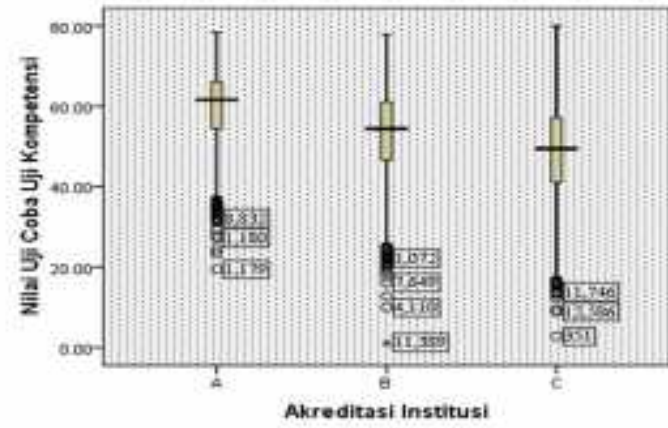

Gambar 2 Sebaran Nilai Peserta Berdasarkan Peringkat Akreditasi

Gambar 2 menunjukkan setiap institusi pendidikan memiliki sebaran nilai hasil uji coba uji kompetensi yang cukup besar. Nilai median yang didapatkan institusi dengan peringkat akreditasi A memiliki nilai yang paling tinggi dibandingkan dengan nilai median dari peserta dengan peringkat akreditasi B dan C. Seluruh peringkat akreditasi memiliki nilai outlier di bagian bawah boxplot dan whisker bagian bawah lebih panjang dari whisker bagian atas. Kondisi ini menandakan sebaran nilai yang didapatkan dari peserta dari setiap peringkat akreditasi memiliki data tidak normal (negative skewness). Nilai peserta dari institusi dengan peringkat akreditasi B memiliki satu nilai ekstrim.

Perbedaan Nilai Hasil Uji Coba Uji Kompetensi Bidan Berdasarkan Peringkat Akreditasi Institusi Pendidikan Diploma III Kebidanan

Nilai uji coba uji kompetensi berdistribusi tidak normal sehingga untuk dapat mengetahui apakah terdapat perbedaan nilai hasil uji coba uji kompetensi bidan berdasarkan peringkat akreditasi institusi pendidikan Diploma III Kebidanan dilakukan menggunakan uji beda Kruskal-Wallis. Hasil uji beda dapat dilihat pada tabel 2.

\section{Tabel 2 Perbedaan Nilai Hasil Uji Coba Uji Kompetensi Bidan Berdasarkan Peringkat Akreditasi Institusi Pendidikan Diploma III Kebidanan}

\begin{tabular}{ccccc}
\hline $\begin{array}{c}\text { Peringkat } \\
\begin{array}{c}\text { Akreditasi } \\
\text { Institusi }\end{array}\end{array}$ & n & $\begin{array}{c}\text { Mean } \pm \\
\text { (sd) }\end{array}$ & $\begin{array}{c}\text { Median } \\
\text { (Min-Maks) }\end{array}$ & p \\
\hline A & 1133 & $59,54(9,31)$ & 61,67 & $<0.01$ \\
& & $53,28(1.03)$ & $(19,44-78,33)$ & \\
B & 4594 & $48,70(1,13)$ & 54,44 & \\
& & & $(1,11-77,78)$ & \\
C & 9534 & & 49,44 & \\
& & & $(2,78-80,00)$ & \\
\hline
\end{tabular}

Keterangan: Uji beda menggunakan uji KruskallWallis

Tabel 2 menunjukkan kelompok peringkat akreditasi A dengan jumlah peserta paling sedikit, yaitu 1.133 orang dengan nilai median tertinggi $(61,67)$ dibandingkan kelompok peringkat akreditasi lainnya. Jumlah peserta terbanyak adalah kelompok peringkat akreditasi C (9.534 orang) dengan nilai median terkecil $(49,44)$ dan rentang nilai yang didapatkan antara 2,78 sampai dengan 80,00 . Nilai $\mathrm{p}<0,01$ pada tabel 2 memberikan gambaran terdapat perbedaan nilai uji coba uji kompetensi yang didapatkan, setidaknya pada dua kelompok akreditasi.

Tabel 3 Analisis Post Hoc

\begin{tabular}{cc}
\hline $\begin{array}{c}\text { Peringkat Akreditasi } \\
\text { Institusi }\end{array}$ & p \\
\hline A dan B & $<0,01$ \\
A dan C & $<0,01$ \\
B dan C & $<0,01$ \\
\hline
\end{tabular}

Analisis Post Hoc dilakukan setelah hasil uji beda didapatkan untuk mengetahui pada kelompok peringkat akreditasi mana saja yang memiliki perbedaan nilai. Analisis yang dilakukan menggunakan uji Mann-Whitney. Tabel 3 menunjukkan pada seluruh kelompok yang dibandingkan didapatkan nilai $\mathrm{p}<0,01$, yang berarti terdapat perbedaan nilai uji coba uji kompetensi pada seluruh kelompok peringkat akreditasi. 


\section{Hubungan Peringkat Akreditasi Institusi Pendidikan Diploma III Kebidanan dengan Hasil Uji Coba Uji Kompetensi Bidan Periode Juli 2013.}

Tabel 4 Hubungan Peringkat Akreditasi Institusi Pendidikan Diploma III Kebidanan dengan Hasil Uji Coba Uji Kompetensi Bidan Periode Juli 2013

\begin{tabular}{|c|c|c|c|c|c|c|c|c|c|c|c|c|}
\hline \multirow{4}{*}{$\begin{array}{l}\text { Peringkat } \\
\text { Akreditasi } \\
\text { Institusi }\end{array}$} & \multicolumn{12}{|c|}{ Hasil Uji Coba Uji Kompetensi Bidan } \\
\hline & \multicolumn{6}{|c|}{ Pencapaian Hasil Belajar } & \multirow{2}{*}{\multicolumn{6}{|c|}{$\begin{array}{c}\text { Nilai Batas Lulus } \\
\geq \mathrm{CO}\end{array}$}} \\
\hline & \multicolumn{2}{|c|}{$<$ median } & \multicolumn{2}{|c|}{$\geq$ median } & \multirow[b]{2}{*}{$\mathbf{r}$} & \multirow[b]{2}{*}{$\mathbf{p}$} & & & & & & \\
\hline & $\mathbf{N}$ & $\%$ & n & $\%$ & & & $\mathbf{n}$ & $\%$ & $\mathbf{n}$ & $\%$ & $\mathbf{r}$ & $\mathbf{P}$ \\
\hline A & 209 & 18,4 & 924 & 81,6 & 0,22 & $<0,01$ & 321 & 28,3 & 812 & 71,7 & 0,23 & $<0,01$ \\
\hline B & 1863 & 40,6 & 2731 & 59,4 & & & 2547 & 55,4 & 2047 & 44,6 & & \\
\hline $\mathrm{C}$ & 5488 & 57,6 & 4046 & 42,4 & & & 6741 & 70,7 & 2793 & 29,3 & & \\
\hline Total & 7560 & 49,5 & 7701 & 50,5 & & & 9609 & 63 & 5652 & 37 & & \\
\hline
\end{tabular}

Tabel 4 menjelaskan hubungan peringkat akreditasi institusi dengan pencapaian hasil belajar dan juga nilai batas lulus diuji dengan uji Somers'd dan didapatkan nilai $p<0,01$. Hasil tersebut berarti terdapat hubungan yang bermakna antara peringkat akreditasi institusi pendidikan Diploma III Kebidanan dengan nilai hasil uji coba uji kompetensi bidan tahun 2013. Uji Somers'd juga memberikan gambaran kekuatan korelasi (r) antara peringkat akreditasi institusi dengan pencapaian hasil belajar dan nilai batas lulus sebesar $r=0,22$ dan $r=0,23$, yang berarti antara peringkat akreditasi institusi pendidikan Diploma III Kebidanan dengan hasil uji coba uji kompetensi bidan memiliki korelasi yang lemah.

\section{Pembahasan}

Gambar 2 memberikan gambaran secara umum tentang hasil penelitian ini. Peserta yang berasal dari institusi dengan peringkat akreditasi A mendapatkan capaian hasil uji coba uji kompetensi yang lebih baik daripada peserta yang berasal dari institusi dengan peringkat akreditasi B dan C.

Kemampuan optimal mahasiswa akan lebih dapat terukur bila menggunakan alat uji yang lebih menekankan pada show how dan does. Pengukuran kompetensi bagi mahasiswa akhir program dapat dilakukan hingga tahap show how, namun penggunaan metode ini belum dapat digunakan dalam uji coba uji kompetensi bidan tahun 2013 terkait masih dalam proses pengembangan. Dengan demikian, metode uji coba uji kompetensi kali ini masih terbatas pada pengukuran kemampuan peserta pada tingkat knows dan knows how yang mengukur pengetahuan dan kemampuan pengambilan keputusan berdasarkan pengetahuan yang dimiliki, yang lebih tepat digunakan pada tahap awal pembelajaran. ${ }^{9,} 14$

Penilaian kompetensi seseorang akan lebih optimal jika digunakan beberapa kombinasi metode uji. Jika metode uji yang digunakan adalah uji tulis mungkin saja peserta mengetahui tindakan terbaik yang harus diambil dalam menghadapi suatu kasus, namun belum tentu saat melakukan tindakan dalam pemberian asuhan, peserta mampu melakukan sesuai apa yang diketahuinya. Hal ini sesuai dengan prinsip yang terkandung pada piramida Miller bahwa penting menilai pengetahuan seseorang, tetapi tidak cukup untuk memprediksi apakah orang tersebut akan menerapkannya dalam praktik. ${ }^{15}$

Perbedaan Peringkat Akreditasi Institusi Pendidikan Diploma III Kebidanan dengan Nilai Hasil Uji Coba Uji Kompetensi Bidan Periode Juli 2013.

Tabel 2 dalam penelitian ini menunjukkan bahwa diantara ketiga kelompok peringkat akreditasi A, B maupun $\mathrm{C}$ terdapat perbedaan pencapaian nilai uji coba uji kompetensi bidan tahun 2013 dengan nilai $p<0,01$. Perbedaan diantara ketiga kelompok tersebut diperkuat oleh uji Post Hoc yang menunjukkan nilai $\mathrm{p}<0,01$ pada seluruh perbandingan yang dilakukan diantara ketiga kelompok tersebut yang ditunjukkan pada tabel 3.

Kesesuaian antara berbagai teori dan hasil penelitian yang didapatkan diperkuat pula oleh hasil penelitian sebelumnya yang dilakukan pada lulusan institusi pendidikan kedokteran di Amerika Serikat. Penelitian tersebut menyatakan peserta dari institusi kelompok peringkat akreditasi A memberikan performa ujian yang 
lebih baik bila dibandingkan dengan lulusan dari kelompok institusi peringkat akreditasi B. Perbedaan tersebut terjadi baik pada jenis uji basic science maupun skill performance. ${ }^{16}$

Hasil uji kompetensi dokter Indonesia juga memberikan hasil serupa. Rerata nilai yang didapatkan oleh peserta dari institusi pendidikan dokter dengan peringkat akreditasi A lebih tinggi dibandingkan dengan peserta yang berasal dari institusi pendidikan kedokteran dengan peringkat akreditasi B dan C. Jumlah lulusan yang dihasilkan oleh institusi yang berasal dari peringkat akreditasi A juga lebih banyak bila dibandingkan dengan lulusan yang dihasilkan oleh institusi dengan peringkat akreditasi B dan C. ${ }^{17}$

Hubungan Peringkat Akreditasi Institusi Pendidikan Diploma III Kebidanan dengan Nilai Hasil Uji Coba Uji Kompetensi Bidan Periode Juli 2013.

Uji coba uji kompetensi tahun 2013 belum memiliki nilai cut off yang membedakan mahasiswa kompeten atau tidak kompeten, namun lebih dilakukan untuk memberikan gambaran dasar kepada peserta maupun institusi asal peserta terhadap pencapaian tiap peserta dan intitusi terhadap standar soal uji kompetensi yang akan dilaksanakan. Dengan demikian, peneliti menggunakan standar nilai minimal mata kuliah, yaitu 56,0 sebagai nilai batas lulus dan juga nilai median yang didapatkan dari nilai uji coba uji kompetensi bidan periode Juli tahun 2013, yaitu 52,00 sebagai pencapaian hasil belajar.

Kelulusan yang dihasilkan jika menggunakan median nilai uji coba uji kompetensi bidan periode Juli 2013 sebagai batas lulus menunjukkan dari institusi pendidikan kebidanan terakreditasi A memberikan persentase lebih besar, yaitu 81,6\% bila dibandingkan dengan peringkat akreditasi B $(59,4 \%)$ dan C $(42,4 \%)$. Persentase kelulusan yang dihasilkan jika menggunakan nilai cut off juga memberikan gambaran yang sama, institusi pendidikan terakreditasi A memberikan kelulusan yang lebih besar (71,7\%) dibandingkan dengan institusi pendidikan kebidanan terakreditasi B $(44,6 \%)$ dan terakreditasi C $(29,3 \%)$.

Penelitian yang dilakukan pada lulusan pendidikan kedokteran di Meksiko dan Filipina memberikan gambaran bahwa institusi pendidikan yang terakreditasi menghasilkan peserta yang lulus uji kompetensi lebih banyak bila dibandingkan dengan institusi pendidikan yang tidak terakreditasi. Institusi pendidikan terakreditasi di Meksiko dapat menyumbang $15 \%$ lebih banyak peserta yang lulus uji kompetensi, sedangkan institusi pendidikan terakreditasi di Filipina memberikan 29,2\% lebih banyak peserta yang lulus uji kompetensi dibandingkan dengan institusi pendidikan yang tidak terakreditasi. ${ }^{18}$

Penelitian lain di Amerika Serikat yang dilakukan pada lulusan pendidikan kedokteran di Negara-negara Karibian dan negara global lainnya memberikan hasil yang serupa pula. Hasil penelitian tersebut menyatakan kelulusan peserta uji kompetensi dari institusi pendidikan terakreditasi pada Negara-negara Karibian memberikan sumbangan 4,9 kali lebih besar pada uji basic skill, 2,3 kali lebih banyak pada clinical knowledge, dan 2,4 kali lebih banyak pada clinical skills dibandingkan dengan yang tidak terakreditasi. Kondisi ini juga terjadi pada negara global lainnya yang diteliti didalam penelitian yang sama. Institusi pendidikan kedokteran yang terakreditasi memberikan kelulusan uji kompetensi 1,8 kali lebih besar pada uji basic skill, 1,3 kali lebih banyak pada clinical knowledge, dan 1,3 kali lebih banyak pada clinical skills. ${ }^{16}$

Tabel 4 menunjukkan lemahnya hubungan antara peringkat akreditasi institusi pendidikan kebidanan dengan hasil uji coba uji kompetensi bidan dapat terjadi karena berbagai faktor. Salah satu faktor yang mungkin dapat memengaruhi kekuatan hubungan tersebut adalah faktor internal peserta uji. Kegiatan uji coba uji kompetensi merupakan kegiatan yang tidak memengaruhi secara langsung kelulusan peserta, sehingga dimungkinkan terdapat peserta yang tidak serius mengerjakan soal-soal yang ada.

Faktor institusi pendidikan asal peserta uji juga dapat memberikan andil dalam memengaruhi hasil uji. Kegiatan uji coba uji kompetensi merupakan kegiatan sukarela yang diikuti oleh mahasiswa dari institusi pendidikan kebidanan. Hasil yang didapatkan institusi pendidikan dapat menjadi tidak objektif bila institusi mengirimkan peserta tanpa mempertimbangkan sebaran prestasi mahasiswa diinstitusinya sehingga gambaran mahasiswa tidak terwakili. 
Perbedaan proses penyelenggaraan pendidikan antar setiap institusi dan belum sesuainya pelaksanaan proses pendidikan dengan kaidah-kaidah yang ditetapkan menjadi salah satu faktor yang menyebabkan kurang kuatnya korelasi antara peringkat akreditasi dengan output institusi. Hal ini diungkapkan dalam penelitian terhadap 54 institusi pendidikan Diploma III bagi tenaga kesehatan di DKI Jakarta. Dalam penelitiannya dinyatakan tidak adanya hubungan antara akreditasi dengan mutu lulusan yang dilihat dari Indeks Prestasi Semester (IPS), Ujian Akhir Program (UAP) maupun Indeks Prestasi Kumulatif (IPK). Kondisi tersebut terjadi baik pada penetapan input yang kurang baik, penetapan dosen yang tidak tepat, materi pengajaran yang kurang cocok, sarana penunjang yang kurang memadai, dan sistem administrasi yang kurang tepat, lahan praktik, proses pendidikan, dan pengajaran yang belum sesuai. ${ }^{19}$

Pemilihan penggunaan bentuk uji yang digunakan juga mungkin dapat memengaruhi kekuatan korelasi yang dihasilkan. Tahun 2013, uji coba uji kompetensi bidan terbatas pada penggunaan uji tulis untuk menilai kemampuan pengetahuan yang dimiliki oleh peserta uji, sedangkan penilaian performa yang menilai show hows masih dalam proses pengembangan. Hal ini mungkin saja dapat memengaruhi hasil penilaian. Oleh karena itu, untuk menilai pencapaian hasil pembelajaran bagi mahasiswa akhir program akan lebih baik bila menggunakan kombinasi metode uji seperti OSCE yang dapat melakukan penilaian maksimal dari simulasi kondisi praktik sesungguhnya. ${ }^{20}$

Penelitian ini tidak mempertimbangkan faktor internal maupun eksternal peserta ujian seperti motivasi dan keseriusan peserta dalam mengikuti kegiatan uji coba yang mungkin dapat memengaruhi hubungan peringkat akreditasi institusi dengan hasil uji coba uji kompetensi.

\section{Simpulan}

Penelitian ini menunjukkan bahwa adanya perbedaan nilai uji coba uji kompetensi bidan berdasarkan akreditasi dan juga adanya hubungan yang lemah antara peringkat akreditasi institusi pendidikan D III Kebidanan dengan hasil uji coba uji kompetensi bidan. Semakin baik peringkat akreditasi institusi maka semakin baik pula hasil uji coba uji kompetensi yang didapatkan.

\section{Daftar Pustaka}

1. Widiyani R. Kualitas Bidan Indonesia diragukan? Dikutip dari: http://health.kompas.com/read/2014/01/31/1153 108/Kualitas.Bidan.Indonesia.Diragukan. Dikutip tanggal 13 Mei 2014.

2. Pusat Pendidikan Tenaga Kesehatan. Profil Pendidikan Tenaga Kesehatan, Jakarta; 2002.

3. Badan Akreditasi Nasional Perguruan Tinggi. Akreditasi Program Studi Diploma: Buku I Naskah Akademik. Jakarta; 2009.

4. Badan Akreditasi Nasional Perguruan Tinggi. Direktori SK Hasil Akreditasi Program Studi. Diakses dari: http://banpt.kemdiknas.go.id/hasil-pencarian.php tanggal 4 Juli 2014.

5. Peraturan Menteri Kesehatan Nomor 1796 Tahun 2011 tentang Registrasi Tenaga Kesehatan

6. Page G. Handbook On Competency-Based Assessment in Indonesian Medical Schools Jakarta: Dikti; 2007.

7. Hopkins K. Educational and Psycological Measurement and Evaluation. MA. 1998. Allyn and Bacon:Needham Heights.

8. Bordage G, Brailovsky C, Carretier H, Page G. Content validation of Key Features on a National Examination of Clinical DecisionMaking Skills. Acad Med 1995. 70:276-81.

9. Bridge PD, Musial J, Frank R, Roe T, Sawilowsky S. Measurement practices: methodes for developing content-valid student examinations. 2003. Med Teach 25:414-21.

10. Bashook PG, Best Practices for Assessing Competence and Performence of The Behavioral Health Workforce, Administration and Policy in Mental Health, Vol.32, No.5/6, May/July 2005.

11. Norcini JJ, Swanson DB, Grosso LJ, Webster GD. Reliability, Validity and Efficiency of Multiple Choice Question and Patient Management Problem Item Formats in Assessment of Clinical Competence. Med Educ 1985;19:238-47 dalam Vleuten CPM, Schuwirth LWT. Assessing Professional Competence: From Methodes to Programmes. Medical Education 2005; 39:309-17.

12. Abdalla ME, Gaffar AM, Sulaiman RA. Constructing A-Type Multiple Choice Questions (MCQs): Step by step Manual. 2011.

13. Asosiasi Institusi Pendidikan Kebidanan Indonesia. Laporan Kegiatan Uji Coba Uji Kompetensi Bidan Indonesia Ketiga tahun 2012. Jakarta; 2012. 
14. Miller GE. The Assessment of Clinical Skills/Competence/Performance. Academic Medicine. 1990. 65:63-7.

15. Kennedy T, Regehr G, Rosenfield J, Roberts W, Lingard L. Degrees of Gap Between Knowledge and Behaviour: A Qualitative Study of Clinician Action Following an Educational Intervention. 2003. Chicago, IL: American Educational Research Association.

16. Van Zanten M. The association between medical education accreditation and the examination performance of internationally educated physicians seeking certification in the United States. PhD [disertasi]. Temple University; 2012.

17. Panitia Uji Kompetensi Dokter Indonesia. Laporan Pelaksanaan Uji Kompetensi Dokter Indonesia XXVIII Periode Mei 2014.
18. Van Zanten M, McKinley D, Durenti MI, Pijano CV. Medical Education Accreditation in Mexico and the Philippines: impact on student outcomes. J Medical Education [abstract]. 2012 [diunduh tanggal 4 Juli 2014]; 46(6):586. Tersedia dari: NCBI.

http://www.ncbi.nlm.nih.gov/pubmed/22626050.

19. Kementerian Pendidikan dan Kebudayaan Republik Indonesia. Surat Edaran Kementerian Pendidikan Tinggi No.160/E/AK/2013 tentang Ijin Penyelenggaraan dan Akreditasi Program Studi, 2013.

20. Wass V, Vleuten CV, Shatzer J, Jones R. Assessment of Clinical Competence, The Lancet.2001.357:945-49 